\title{
How do we choose a therapeutic regimen in cystic fibrosis?
}

\section{F Robertson}

As the range of treatments for cystic fibrosis increases and the costs rise, the clinician is faced with an increasingly complex dilemma to develop a treatment schedule that provides optimal benefit, given financial restraints and the impact of an increasingly complex therapeutic regimen on patient adherence.

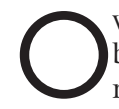
ver the past 20 years there has been an exponential increase in research to develop new treatments for the management of cystic fibrosis-particularly following the identification of the CFTR protein and its impact on the composition and function of the surface epithelial cell airway surface liquid. While early progress was achieved in gene therapy, it is the pharmacological modulation of function of the CFTR protein and the airway surface liquid that is more likely to be translated into treatment.

One of the major consequences of the defect in CFTR production is alteration of the airway surface liquid to impair mucociliary clearance and promote infection. There have been several attempts to alter the properties of the airway surface liquid and to reduce the viscosity of the mucus to improve mucociliary clearance. Agents investigated include recombinant human rhDNase, ${ }^{1}$ hypertonic saline, $^{2}$ dry powder mannitol, ${ }^{3}$

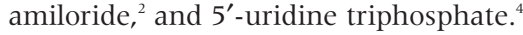
Each has shown a modest benefit and rhDNase has been successfully introduced into the therapeutic routine of many cystic fibrosis centres.

The role of rhDNase was reviewed in Thorax some years ago. ${ }^{5}$ It has been subjected to two prolonged randomised placebo controlled trials in cystic fibrosis. ${ }^{6} 7$ The first compared administration twice daily with once daily and placebo over a 24 week period. ${ }^{6}$ The drug produced an initial improvement in lung function and a reduced risk of respiratory exacerbations. The study failed to show a benefit for twice daily administration over that of single dose administration and the rate of decline in lung function after the initial improvement was not different from placebo. In fact, the initial $9 \%$ improvement in $\mathrm{FEV}_{1}$ after 2 weeks had fallen to $5 \%$ above placebo at 24 weeks. A similar study of once daily treatment over 24 months in young children with mild disease showed an initial improvement in lung function which was sustained over a 2 year period and a reduced risk of respiratory tract exacerbation. However, the rate of decline in lung function after the initial improvement was no different from that with placebo. ${ }^{7}$ This benefit comes at a considerable cost of approximately $£ 7500$ per annum $^{8}$ yet, despite the clear initial benefits, it remains unclear whether rhDNase has a positive outcome on the long term outcome in cystic fibrosis

Hypertonic saline has been shown to improve mucociliary clearance and, in short term studies, ${ }^{9}$ results in a similar improvement in lung function to that observed with rhDNase. ${ }^{10}$ The mechanism by which hypertonic saline is thought to achieve its benefit is by its favourable effect on mucus rheology and altering the osmotic composition of the airway surface liquid. ${ }^{11}$ The lung has the ability to rapidly render inhaled solutions isotonic so the effect of any hyperosmolar aerosol will be dependent on the dose and rate of delivery.

Development costs of new pharmaceutical agents determine their high cost to the consumer. In a study reported in this issue of Thorax Suri et $a l^{8}$ have attempted to compare the cost and the effectiveness of daily administration of rhDNase with that of alternate day administration and hypertonic saline. The authors were able to show that alternate day rhDNase was equally as effective as daily treatment and had a moderate cost advantage. Hypertonic saline was found not to be as effective as rhDNase in improving lung function but offered a considerable cost advantage.

Previous clinical trials that showed inhaled mucociliary clearance and improvement in lung function used a dose of $10 \mathrm{ml}$ of either $6 \%$ or $7 \%$ saline delivered via ultrasonic nebuliser. ${ }^{2}{ }^{9}$ The ultrasonic nebuliser delivers a large volume over a short period of time and has a small residual volume ensuring delivery of approximately $9 \mathrm{ml}$ per dose. The jet nebuliser used in the current study was filled with a loading dose of $5 \mathrm{ml}$ and would deliver approximately $4 \mathrm{ml}$ over the same time period. As the proposed mechanism of effect for hypertonic saline is dependent on dose and rate of delivery of the hyperosmolar aerosol, ${ }^{11}$ the lack of benefit from hypertonic saline observed in this study may be a result of the low dose delivered. It is disappointing that the methodology which had been shown to be effective in earlier clinical trials was not used in the currently reported comparative study. So the question regarding the effectiveness of hyperosmolar aerosols used over a longer period of time remains unanswered.

Cystic fibrosis is a lifelong disease with an extremely variable outcome. In an era when the range of pharmaceuticals available for the management of cystic fibrosis is expanding and where each conveys a modest benefit to the patient, difficult decisions have to be made. Judgements of the benefits of new treatments on long term outcome must be extrapolated from relatively short term clinical trials. The clinician is faced with an increasingly complex dilemma to develop a treatment schedule that provides optimal benefit, given financial restraints and the impact of an increasingly complex therapeutic regimen on patient adherence. Furthermore, as costs of pharmaceuticals escalate, the clinician may be faced with capping of healthcare expenditure. When limited to a fixed sum per patient per year for comprehensive health care, how should the clinician best spend it in a patient with cystic fibrosis? Suri et al ${ }^{11}$ have clearly shown that alternate day treatment with rhDNase is equally as effective as daily treatment, not only providing a cost advantage but simplifying the therapeutic regimen and reducing the burden for the patient.

Thorax 2002;57:839-840

Correspondence to: A/Prof CF Robertson, Department of Respiratory Medicine, Royal Children's Hospital, Parkville 3052, Victoria, Australia; cfrob@cryptic.rch.unimelb.edu.au

\section{REFERENCES}

1 Robinson $M$, Hemming AL, Moriarty $C$, et al. Effect of a short course of rhDNase on cough and mucociliary clearance in patients with cystic fibrosis. Pediatr Pulmonol 2000;30: 16-24

2 Robinson M, Regnis JA, Bailey DL, et al. Effect of hypertonic saline, amiloride, and cough on mucociliary clearance in patients with cystic fibrosis. Am J Respir Crit Care Med 1996;153:1503-9

3 Robinson M, Daviskas E, Eberl S, et al. The effect of inhaled mannitol on bronchial mucus clearance in cystic fibrosis patients: a pilot study. Eur Respir J 1999; 14:678-85.

4 Bennett WD, Olivier KN, Zeman KL, et al. Effect of uridine 5'-triphosphate plus amiloride on mucociliary clearance in adult cystic fibrosis. Am J Respir Crit Care Med 1996;153:1796-801. 
5 Zach MS. The role of recombinant human DNase in the treatment of patients with cystic fibrosis: many promises, more problems. Thorax 1996:51:750-5.

6 Fuchs HJ, Borowitz DS, Christiansen DH, ef al. Effect of aerosolized recombinant human DNase on exacerbations of respiratory symptoms and on pulmonary function in patients with cystic fibrosis. The Pulmozyme Study Group. N Engl J Med 1994;331:637-42.
7 Quan JM, Tiddens HA, Sy JP, et al. A two-year randomized, placebo-controlled trial of dornase alfa in young patients with cystic fibrosis with mild lung function abnormalities. J Pediatr 2001;139:813-20.

8 Suri R, Grieve R, Normand C, et al. Effects of hypertonic saline, alternate day and daily rhDNase on health care use, cost and outcomes in children with cystic fibrosis. outcomes in children with
Thorax 2002:57:841-6.

9 Eng PA, Morton J, Douglass JA, et al. Short-term efficacy of ultrasonically nebulized hypertonic saline in cystic fibrosis. Pediat Pulmonol 1996;21:77-83.

10 Ranasinha C, Assoufi B, Shak S, et al. Efficacy and safety of short-term administration of aerosolised recombinant human DNase I in adults with stable stage cystic fibrosis. Lancet 1993;342: 199-202.

11 Robinson M, Hemming AL, Regnis JA, et al. Effect of increasing doses of hypertonic saline on mucociliary clearance in patients with cystic fibrosis. Thorax 1997:52:900-3.

\section{Clinical Evidence-Call for contributors}

Clinical Evidence is a regularly updated evidence based journal available world wide both as a paper version and on the internet. Clinical Evidence urgently needs to recruit a number of new contributors. Contributors are health care professionals or epidemiologists with experience in evidence based medicine and the ability to write in a concise and structured way.

We are presently interested in finding contributors with an interest in the following clinical areas:

$\begin{array}{ll}\text { Angina pectoris } & \text { Hepatitis C } \\ \text { Attention deficit hyperactivity disorder } & \text { HIV } \\ \text { Genital warts } & \text { Influenza } \\ \text { Hepatitis B } & \text { Varicose veins }\end{array}$

Being a contributor involves:

- Appraising the results of literature searches (performed by our Information Specialists) to identify high quality evidence for inclusion in the journal.

- Writing to a highly structured template (about 1500-3000) words), using evidence from selected studies, within 6-8 weeks of receiving the literature search results.

- Working with Clinical Evidence Editors to ensure that the text meets rigorous epidemiological and style standards.

- Updating the text every eight months to incorporate new evidence.

- Expanding the topic to include new questions once every eight months to incorporate new evidence.

- Expanding the topic to include new questions once every 12-18 months.

If you would like to become a contributor for Clinical Evidence or require more information about what this involves, please send your contact details and a copy of your $\mathrm{CV}$, clearly stating the clinical area you are interested in, to Polly Brown (pbrown@bmigroup.com). 